DOI 10.14746/ssp.2018.2.8

Anita ADAMCZYK

Uniwersytet im. Adama Mickiewicza w Poznaniu

\title{
Imigracja zarobkowa do Polski. Casus Ukraińców (2014-2017)
}

Streszczenie: Celem artykułu jest analiza imigracji zarobkowej Ukraińców do Polski w latach 2014-2017. W nim przedstawiono dane będące wynikiem badań ukraińskich i polskich instytucji w zakresie migracji ukraińskich pracowników. Przeanalizowano statystyki dotyczące ich aktywności na polskim rynku pracy. Ukazano także wpływ ukraińskich pracowników na rozwój ekonomiczny Polski. W artykule postawiono tezę, że aktywność Ukraińców miała pozytywny wpływ na rozwój polskiej gospodarki.

Słowa kluczowe: imigracja zarobkowa, Ukraińcy, rynek pracy, cudzoziemcy

W

spółcześnie Ukraina należy do najważniejszych państw będących źródłem imigracji zarobkowej do Polski. Charakteryzuje się ona najczęściej krótkimi okresami pobytu w Polsce oraz cyrkulacją (sezonowość). Poza tym można zauważyć powolny wzrost imigracji na dłuższe pobyty (powyżej 12 miesięcy), jak i na stałe.

Przedmiotem analizy niniejszego artykułu jest aktywność ukraińskich obywateli na polskim rynku pracy. W nim przedstawiono czynniki przyciągające i odpychające, które miały decydujący wpływ na emigrację zarobkową z Ukrainy do Polski. Przeanalizowano wielkość zatrudnienia Ukraińców na podstawie zezwoleń na pracę i oświadczeń o powierzeniu wykonywania pracy w latach 2014-2017. Ukazano zmiany w polskim ustawodawstwie oraz wpływ obecności Ukraińców na polski rynek usług. W artykule postawiono tezę, że pracownicy ukraińscy mieli pozytywny wpływ na rozwój polskiej gospodarki. Badając powyższą problematykę, zasadne wydaje się postawienie kilku pytań badawczych: jakie czynniki zdecydowały o wyborze polskiego rynku pracy przez Ukraińców?; jakie zmiany w zatrudnieniu cudzoziemców, w tym Ukraińców, weszły w życie z dniem 1 stycznia 2018 roku?; ilu Ukraińców było zatrudnionych legalnie w Polsce na podstawie zezwoleń na pracę i oświadczeń?; w jakich branżach i zawodach Ukraińcy domino- 
wali?; jak obecność Ukraińców wpływała na polską gospodarkę? Interdyscyplinarne podejście do badanego zjawiska wymusiło zastosowanie różnych metod badawczych, w tym metody instytucjonalno-prawnej, decyzyjnej i komparatystycznej.

Decyzje o wyjeździe zarobkowym Ukraińców podyktowane były przede wszystkim złą sytuacją ekonomiczną w państwie (niski wzrost gospodarczy, wysoka inflacja, wzrost bezrobocia, spadek wartości hrywny, niskie zarobki), rosnącą pauperyzacją społeczeństwa ukraińskiego oraz konfliktem zbrojnym wybuchłym w 2014 roku (w wyniku, którego utracono między innymi zindustrializowaną część państwa). Między Ukrainą a Polską pojawiła się ogromna dysproporcja w zakresie PKB per capita. Podczas, gdy na Ukrainie w latach 2014-2017 produkt krajowy brutto oscylował między 3095 a 2135 dolarów (Ukraine), to w Polsce między 14337 a 13429 dolarów (Poland). Dostrzegalne różnice były także między poziomem bezrobocia, które na Ukrainie wahało się między 9,1\% a 9,5\% w okresie 2014-2017 (Ukraine - Unemployment), a w Polsce między 9\% a 4,8\% (Poland - Unemployment). Dysproporcje dotyczyły poza tym średniego miesięcznego wynagrodzenia. W okresie od stycznia do kwietnia 2016 roku wynosiło ono na Ukrainie 4686 hrywien (czyli około 712 zł wg kursu z maja 2016 roku - The average, 2016), a w Polsce w pierwszym kwartale 2016 roku w gospodarce narodowej średnie miesięczne wynagrodzenie równe było 4181 zł brutto (a w sektorze przedsiębiorstw - 4202 zł brutto - Wynagrodzenia). Rozbieżności te mogły tłumaczyć zainteresowanie polskim rynkiem pracy przez Ukraińców. Emigracja zarobkowa z Ukrainy miała związek także z brakiem rozwoju gospodarczego w tym państwie. Widoczne to było między innymi w nieotwieraniu nowych firm, nierozwijaniu nowych branż czy wdrażaniu innowacji. Ponadto władze ukraińskie nie czyniły nic, aby zatrzymać pracownika przed wyjazdem za granicę. Na Ukrainie dostrzeżono również niedostatki w rozwoju społecznym, gospodarczym i moralnym, co rzutowało na brak perspektyw w tym państwie (Бойко, 2017). Czynniki te miały wpływ na podjęcie decyzji o emigracji z Ukrainy. Według danych statystycznych z 2017 roku państwo to opuściło około 7000000 obywateli. Wpływ na decyzję o wyjeździe miała nadzieja na lepsze warunki życia (64\%), brak pracy na Ukrainie (23\%) i podniesienie wykształcenia $(12 \%)($ Кожен, 2017). Według badań statystycznych z września 2017 roku respondenci Ukraińcy wykazywali najczęściej chęć podjęcia pracy w Niemczech (37\%), Polsce (26\%), USA (22\%), Kanadzie (21\%), Czechach (15\%) i Włoszech (15\%) (Скільки, 2017). 
Z badań ukraińskich wynika, iż w 2016 roku, w porównaniu do lat poprzednich, wzrosła liczba Ukraińców deklarujących chęć opuszczenia ojczyzny. Grupa ta stanowiła wówczas $65 \%$ badanych (w tym $20 \%$ na stałe), podczas gdy we wrześniu 2015 roku - 57\% (w tym 13\% na stałe), a w listopadzie 2014 roku - 45\% (w tym 10\% na stałe) (Все більше, 2016). Chęć wyjazdu deklarowały przede wszystkim osoby młode do 30 roku życia (55\%) (Перспективні, 2017).

Z „Raportu inflacyjnego" Narodowego Banku Ukraińskiego wynika także, iż 1300000 Ukraińców w wieku 15-70 lat pracowała za granicą (dotyczyło to badań przeprowadzonych w okresie od 2015 do połowy 2017 roku). 43,2\% wyjeżdżała na krótkie okresy (Інфляційний, 2018, s. 28). Najczęściej kierowali się oni do Rosji, Polski, Włoch i Czech. W 2017 roku odnotowano spadek emigracji zarobkowej do Rosji i wzrost do Polski (ibidem). Na wyjazd decydowali się mężczyźni ze średnim i wyższym wykształceniem. Jedynie $26,8 \%$ emigrantów ukraińskich pracowało zgodnie ze swoimi kwalifikacjami (ibidem, s. 29). Jak zauważono, emigracja z Ukrainy nie była pozytywnym zjawiskiem. Stanowiła zagrożenie dla rozwoju rodzimego rynku pracy, systemu emerytalnego i obniżenia potencjalnego wzrostu gospodarczego. Poza negatywnymi konsekwencjami, miała także pozytywne strony jak na przykład transfery środków pieniężnych z zagranicy, co było źródłem inwestycji, zmniejszenia ubóstwa i spadku napięcia na rynku pracy (ibidem, s. 30).

Z polskiej perspektywy imigracja zarobkowa Ukraińców była i jest cennym zjawiskiem. Pracownicy Ukraińcy wypełniali bowiem luki na polskim rynku pracy powstałe na skutek niżu demograficznego, odchodzenia na emeryturę i obniżenia wieku emerytalnego w 2017 roku $^{1}$, wyjazdu Polaków za granicę czy rezygnacji z pracy po otrzymaniu świadczeń z programu „Rodzina 500 plus”. Ich zatrudnienie nie generowało wzrostu bezrobocia. Odnalezieniu się ich na polskim rynku pracy sprzyjała bliskość geograficzna i kulturowo-językowa. Jednak i to mogło okazać się czasami przeszkodą, bowiem sąsiedztwo oraz związane z nim zaszło-

1 Od 1 września 2017 roku, kiedy można było składać wnioski o przyznanie emerytury (po reformie, zgodnie z którą kobiety uzyskały prawo przejścia na emeryturę w wieku 60 lat, a mężczyźni 65 lat) do 16 grudnia 2017 roku do ZUS wpłynęło 413000 wniosków, z których 379208 zostało pozytywnie rozpatrzonych. Rok 2017 na rynku pracy: obniżenie wieku emerytalnego, wyższa płaca minimalna, zmiany w 500 plus (2017), „Gazeta Prawna”, 30.12.2017 r., http://serwisy.gazetaprawna.pl/ praca-i-kariera/artykuly/1094793,rok-2017-na-rynku-pracy-obnizenie-wieku-emerytalnego-wyzsza-placa-minimalna.html. 
ści historyczne mogły utrudniać integrację imigranta ze społeczeństwem przyjmującym.

Z punktu widzenia ukraińskiego imigranta zarobkowego ważne było poczucie bezpieczeństwa, które miało związek z bliskością do domu. Istotne znaczenie w wyborze państwa emigracji zarobkowej przez Ukraińców miało także istnienie $\mathrm{w}$ Polsce sieci migracyjnych. Zgodnie $\mathrm{z}$ tą teorią ,[...] decyzje o zmianie miejsca pobytu są wynikiem interpersonalnych kontaktów między powracającymi z danego kraju (lub tam przebywającymi) a zamierzającymi się tam wybrać. Ci pierwsi stanowią cenne źródło informacji na temat samej migracji (korzyści, strat, problemów, kwestii związanych z pracą czy zakwaterowaniem)" (Adamczyk, 2012, s. 37). Istnienie sieci migracyjnych w rezultacie prowadziło do tzw. łańcucha migracji.

Istotnymi elementami przyciagającymi ukraińskich pracowników były także łatwość w przekraczaniu granicy i podjęcia legalnej pracy w Polsce w porównaniu z innymi państwami UE. Ostatnie zmiany w tym zakresie miały miejsce w 2017 roku. Dotyczyły one zniesienia obowiązu wizowego dla podróżujących z Ukrainy do państw UE oraz zmian w ustawie o promocji zatrudnienia i instytucjach rynku pracy. Decyzję o liberalizacji systemu wizowego dla Ukrainy podjęto 11 maja 2017 roku po przyjęciu przez Radę UE wniosku Komisji Europejskiej w tej sprawie. Następnie 17 maja 2017 roku Parlament Europejski i Rada UE wydały stosowne rozporządzenie (Rozporządzenie Parlamentu, 2017). Obowiązuje ono na terenie wszystkich państw członkowskich, poza Wielką Brytanią i Irlandią oraz czterema państwami stowarzyszonymi z Schengen. Pobyt bez obowiązku posiadania wizy nie może trwać dłużej niż 90 dni w ciagu każdego 180-dniowego okresu (art. 1 ust. 2 Rozporządzenia Rady, 2001). Zgodnie z prawem unijnym wszystkie pobyty krótkoterminowe są sumowane. Jeśli ten czas zostanie wykorzystany przez daną osobę, to musi się ona ubiegać o wizę długoterminową. W celu korzystania z ruchu bezwizowego wymaga się od Ukraińców posiadania paszportu biometrycznego. Poza tym muszą oni uzasadnić cel i warunki planowanego pobytu, posiadać środki finansowe ( 300 zł do trzech dni i 75 zł na każdy kolejny dzień pobytu) oraz ubezpieczenie (rt, adom, 2017). Ich nazwiska nie mogą być umieszczone w bazie osób, którym odmówiono wjazdu oraz które zagrażają porząadkowi publicznemu i bezpieczeństwu wewnętrznemu. $Z$ jednej strony wprowadzenie tych udogodnień może mieć wpływ na nasz rynek pracy, bowiem ruch bezwizowy pozwala Ukraińcom wyjechać znacznie dalej niż do Polski i poznać nowe rynki pracy. $Z$ drugiej jednak strony 
w Polsce, w przeciwieństwie do innych państw członkowskich, Ukraińcy mają zagwarantowany system ułatwień umożliwiający im legalne zatrudnienie. Gdy państwa unijne zmienią swoje ustawodawstwo i zliberalizują zatrudnienie Ukraińców (szczególnie przy pracach sezonowych), to będziemy mogli mieć powody do obaw. Z badań Ośrodka Studiów Wschodnich wynika jednak, że Polska nie straci pozycji lidera dla ukraińskich imigrantów zarobkowych (Zniesienie obowiazku, 2017, s. 5).

Do innych modyfikacji prawnych należy zaliczyć nowelizację ustawy o promocji zatrudnienia i instytucjach rynku pracy, której zmiany weszły w życie w dniu 1 stycznia 2018 roku (Ustawa, 2017). Dzięki nim wynagrodzenie określone $\mathrm{w}$ umowie dla cudzoziemca nie może być niższe od pensji pracowników wykonujących porównywalny rodzaj pracy lub pracujących na porównywalnym stanowisku (art. 88c ust. 1). Ponadto nie może być niższa od wysokości minimalnego wynagrodzenia za pracę (art. 88c ust. 1a). Dotyczy to także pracy sezonowej (art. 880), nowej kategorii, która została wprowadzona do ustawy. Pojawienie się jej w ustawie miało związek z implementacją do polskiego systemu prawnego postanowień dyrektywy Parlamentu Europejskiego i Rady 2014/36/ UE z dnia 26 lutego 2014 roku w sprawie warunków wjazdu i pobytu obywateli państw trzecich w celu zatrudnienia w charakterze pracownika sezonowego (Dyrektywa, 2014).

W znowelizowanej ustawie określono: organ właściwy do wydania zezwolenia na pracę sezonową, warunki jego wydania, kwestie dotyczące rozpatrzenia wniosku o zezwolenie, ewidencji, treści zezwolenia, okresu ważności, przedłużenia, uchylenia oraz zakwaterowania cudzoziemca posiadającego zezwolenie na pracę sezonową (art. 88n, 88o, 88p, 88q, $88 \mathrm{r}, 88 \mathrm{~s}, 88 \mathrm{t}, 88 \mathrm{u}, 88 \mathrm{v}, 88 \mathrm{w}, 88 \mathrm{x}, 88 \mathrm{y})$. Zezwolenie na pracę sezonową, zgodnie z ustawa, wydaje starosta na okres do 9 miesięcy w roku. Zezwolenie to może dotyczyć takich podklas działalności PKD, jak: rolnictwo, leśnictwo, łowiectwo i rybactwo oraz działalność związaną z zakwaterowaniem i usługami gastronomicznymi (Rozporządzenie, 2017d). Nowy typ zezwolenia określono literką, „S” (§ 2 pkt 6 Rozporządzenie, 2017a).

Na mocy rozporządzenia z dnia 8 grudnia 2017 roku złożenie wniosku o zezwolenie na pracę sezonową (i jego przedłużenie) oraz oświadczenie o powierzeniu wykonywania pracy cudzoziemcowi kosztuje $30 \mathrm{zł}$ (Rozporządzenie, 2017b). Obowiązuje to od 1 stycznia 2018 roku. Do tego okresu oświadczenie o zamiarze powierzenia wykonywania pracy cudzoziemcowi było bezpłatne. Wprowadzenie opłaty podyktowane było likwidacją procederu fikcyjnych oświadczeń. 
Według badań przeprowadzonych przez agencję pośrednictwa pracy OTTO Work Force Polska i Wyższą Szkołę Handlową we Wrocławiu $60 \%$ Ukraińców przybywających do Polski nabyło bowiem oświadczenie drogą nielegalną. Łączny koszt znalezienia pracy i wystawienia oświadczenia wahał się między 450 a 880 zł (Keryk, 2017, s. 105). Państwowa Inspekcja Pracy odnotowała negatywne zjawisko wykorzystywania systemu oświadczeń przez podmioty świadczące działalność outsourcingową. Prowadzone były one często przez obywateli Ukrainy. Zajmując się sprowadzaniem pracowników z Ukrainy do Polski rejestrowali dużą liczbę oświadczeń w powiatowych urzędach pracy wiedząc, że cudzoziemcy nie będą u nich pracowali. Prowadząc nielegalne pośrednictwo pracy pozyskiwali ich dla innych firm, z którymi zawarli umowy o kooperacji (Sprawozdanie, 2016, s. 142). Podmioty te działały wirtualnie bez zarejestrowania działalności gospodarczej w Polsce. Do rejestracji oświadczeń wykorzystywano osoby bezrobotne i bezdomne, które wcześniej założyły swą fikcyjną działalność gospodarczą, za co otrzymywały pieniądze (Żebrowski, Dyjak, 2017). Łukasz Komuda, redaktor portalu rynekpracy.pl wycenił „rynek oświadczeń” na około ćwierć miliarda euro (ibidem).

W ustawie przyjęto również rozwiązanie. na mocy którego wojewoda może wydać decyzję odmowną wydania zezwolenia na pracę, jeżeli w danym roku został przekroczony limit zezwoleń na pracę (art. 88j ust. 2a). Maksymalną liczbę zezwoleń na pracę określają w drodze rozporządzenia minister właściwy ds. pracy w porozumieniu z ministrem właściwym ds. gospodarki i ds. wewnętrznych (art. 90b ust. 1). Wyznaczając ją biorą pod uwagę potrzeby rynku pracy, względy bezpieczeństwa państwa i porządku publicznego oraz zasadę komplementarności zatrudnienia cudzoziemców w stosunku do obywateli Polski. Limit zezwoleń ma dotyczyć województw, zawodów, rodzajów umów, rodzajów działalności podmiotu powierzającego pracę według klasyfikacji PKD. Odnosić ma się to także do zezwoleń na prace sezonowe i oświadczeń. W pierwszym przypadku porozumiewają się ministrowie właściwi ds. rolnictwa, gospodarki i spraw wewnętrznych (art. 90b ust. 2). W drugim tylko ministrowie właściwi ds. gospodarki i spraw wewnętrznych (art. 90 b ust. 3).

Nowe przepisy $\mathrm{w}$ zakresie zatrudniania imigrantów w pierwszym miesiącu wejścia ich w życie wywołały chaos w urzędach pracy. Proces wydawania oświadczeń wydłużył się i jak wskazują eksperci Personnal Servis, każdego dnia rejestrowanych było 10 razy mniej oświadczeń niż 
rok wcześniej (Zatory, 2018). Związane było to z koniecznością wpisywania danych do oświadczenia przez pracownika urzędu, a nie jak dotąd przez pracodawcę. Należy także zauważyć, iż braki formalne we wniosku oraz duże zainteresowanie wydaniem nowych oświadczeń wydłużyło okres oczekiwania nawet do trzech tygodni (Danielewicz, 2018). Taka sytuacja może rodzić patologiczne zachowanie polegające na podjęciu pracy wbrew prawu w okresie oczekiwania na właściwy dokument legalizujący zatrudnienie. Inną niedogodnością dla cudzoziemca przebywającego jeszcze w ojczyźnie jest zmiana pracodawcy. Od 2018 roku chęć uczynienia tego pociąga za sobą konieczność przyjazdu do Polski i rejestracji u nowego pracodawcy. Wcześniej ważne było posiadanie oświadczenia, które umożliwiało przyjazd do Polski i podjęcie pracy u innego pracodawcy (Zatory, 2018).

Po zmianach prawnych nie będzie można już dokonywać porównań danych dotyczących rejestracji oświadczeń o zamiarze powierzenia pracy cudzoziemcowi zarejestrowanych przed 2017 rokiem z informacjami po 1 stycznia 2018 roku. Ma to związek z wprowadzeniem nowej formuły oświadczenia o powierzeniu wykonywania pracy cudzoziemcowi dotyczącej prac niesezonowych.

Reasumując, po modyfikacji prawnej zatrudnienie cudzoziemców, w tym Ukraińców, będzie odbywało się na podstawie: zezwoleń na pracę wydawanych przez wojewodów, zezwoleń na prace sezonową wydawanych przez starostów w powiatowych urzędach pracy i oświadczeń o powierzeniu wykonywania pracy cudzoziemcowi, składanych przez pracodawcę w powiatowym urzędzie pracy. Na mocy rozporządzenia z dnia 8 grudnia 2017 roku określono listę państw, których obywatele mogą ubiegać się o zezwolenie na pracę sezonową oraz oświadczenie o powierzeniu wykonywania pracy cudzoziemcowi. Są to te same państwa, których obywatele wcześniej mogli starać się o oświadczenie o zamiarze powierzenia wykonywania pracy, czyli Republika Armenii, Republika Białorusi, Gruzja, Republika Mołdawii, Federacja Rosyjska i Ukraina (§ 2 Rozporządzenia, 2017c).

Obecność Ukraińców na polskim rynku pracy zaowocowała powstaniem Międzyzakładowego Związku Zawodowego Pracowników Ukraińskich. Miało to miejsce w maju 2016 roku. Jest to wspólna inicjatywa Ogólnopolskiego Porozumienia Związków Zawodowych i Stowarzyszenia Ukraina-Polska. Organizacja ta postawiła przed sobą cele związane z pomocą w zakresie zatrudnienia, poprawą warunków pracy obywateli Ukrainy w Polsce, przeciwdziałaniem nadużyciom na pol- 
skim rynku pracy i ochroną praw pracowniczych (Powstat, 2017). Jego istnienie jest zasadne, bowiem stale rośnie liczba ukraińskich pracowników w Polsce, co jest związane ze zwiększającym się zapotrzebowaniem na siłę roboczą.

Jak wynika z badań opublikowanych w raporcie „Niedobór talentów”, w 2016 roku, przez firmę doradztwa personalnego ManpowerGroup 45\% polskich pracodawców sygnalizowało kłopoty w znalezieniu pracowników (w 2015 roku - 41\%, a 2014 roku - 33\%, Rozgryźć, 2016, s. 1). Najtrudniej było znaleźć wykwalifikowanych pracowników fizycznych (mechaników, elektryków, spawaczy, monterów, murarzy, stolarzy, tokarzy, drukarzy), kierowców oraz inżynierów (ibidem, s. 2). Niedobór pracowników plasował nas na 18 miejscu wśród 43 badanych państw, z których na pierwszych trzech miejscach były: Japonia (86\%), Tajwan (73\%) i Rumunia (72\%) (ibidem, s. 3). Wyniki tych badań miały związek z rosnącą liczbą wolnych miejsc pracy w naszym kraju. Na koniec grudnia 2016 roku 3,8\% podmiotów zatrudniających jedną lub więcej osób dysponowało wolnymi miejscami pracy, z czego 87,6\% dotyczyła sektora prywatnego, a reszta państwowego (Popyt, 2017, s. 17). Z kolei w III kwartale 2017 roku liczba wolnych miejsc pracy wyniosła 131200 i była wyższa niż w II kwartale o 7,5\% (Monitoring, 2017, s. 1). Wolne miejsca pracy, podobnie jak w 2016 roku, dotyczyły sektora prywatnego $(88,9 \%)$. Najwięcej wolnych miejsc według sekcji PKD w obu badanych okresach dotyczyło przetwórstwa przemysłowego (26\% i $25,5 \%)$, handlu i napraw pojazdów samochodowych (17,6\% i 15,9\%), transportu i gospodarki magazynowej ( $8 \% \mathrm{w} 2016 \mathrm{roku}$ ) oraz budownictwa $(15,5 \%$ na koniec III kwartału 2017 roku) (Popyt, 2017, s. 18; Monitoring, 2017, s. 1). Poszukiwano przede wszystkim robotników przemysłowych i rzemieślników (21,9\% i 29,6\%), specjalistów i pracowników o wysokich kwalifikacjach zawodowych (20,4\% i 16\%), jak również operatorów oraz monterów maszyn i urządzeń (14,2\% i 15,8\%) (Popyt, 2017, s. 19; Monitoring, 2017, s. 2). Najwięcej ofert pracy pod koniec 2016 i III kwartału 2017 roku było w województwach: mazowieckim, wielkopolskim i śląskim (Popyt, 2017, s. 19; Monitoring, 2017, s. 3).

Jak wykazali w swoich badaniach eksperci Personnal Servis (za drugie półrocze 2017 roku) 19\% przedsiębiorców zamierzało szukać ukraińskich pracowników (Barometr, 2017). Najbardziej zainteresowane były duże firmy zatrudniające powyższej 250 pracowników (42\%). Wśród branż deklarujących popyt na kadrę z Ukrainy wyróżniały się sektory produkcji (33\%) i usług (22\%) (ibidem, s. 10). Pracowników zamierzano pozyskać 
poprzez agencje zatrudnienia, polskie urzędy pracy oraz kontakty z przebywającymi już w Polsce Ukraińcami (ibdiem, s. 11). Ta ostatnia forma rekrutacji była najbardziej rozpowszechniona wśród obywateli Ukrainy szukających w Polsce zatrudnienia. Potwierdzają to wyniki badań przeprowadzone z inicjatywy Narodowego Banku Polskiego (NBP) na ukraińskich respondentach $\mathrm{z}$ aglomeracji warszawskiej. Na ich podstawie można wywnioskować, iż 70\% ankietowanych skorzystało z kontaktów rodziny lub znajomych w celu znalezienia pracy, $15 \%$ z ogłoszenia pracodawcy, a 11\% usług pośrednika (Chmielewska, Dobroczek, Puzynkiewicz, 2016, s. 16).

Po 2014 roku w gronie zatrudnionych Ukraińców, według NBP, wzrósł udział mężczyzn (wcześniej dominowały kobiety), co miało wpływ na większe ich zatrudnienie w sektorze usług remontowo-budowlanych (wcześniej dominował sektor usług gospodarstwa domowego) (ibidem, s. 17). Często wykonywali oni pracę poniżej swoich kwalifikacji. Z badań NBP wynikało, że średnio ukraiński imigrant pracował więcej niż Polak (54 godziny tygodniowo). W 2014 roku średnie jego zarobki wynosiły 2105 zł miesięcznie, podczas gdy według GUS średnia pensja brutto dla Polaka równa była 3292 zł (ibidem, s. 20). Część swoich zarobionych pieniędzy pracownik ukraiński transferował na Ukrainę, a pozostałą wydawał w Polsce.

Spora liczba ukraińskich pracowników w Polsce miała wpływ na rozwój sektora usług. Na przykład, banki korzystając z ich obecności przygotowały specjalne dla nich oferty. Okazało się bowiem, że Ukraińcy spośród innych cudzoziemców przebywających w Polsce stanowili najliczniejszą ich klientelę. W jednym z banków ich liczba wzrosła o 130\% w okresie od III kwartału 2016 roku do III kwartału 2017 roku (Wrotniak, 2017a). Banki oferowały obsługę, materiały informacyjne i strony internetowe w języku ukraińskim oraz specjalne warunki dla kont osobistych czy przelewów pieniężnych na Ukrainę (Wrotniak, 2017b). Obecność Ukraińców w Polsce dostrzegli także przedstawiciele sieci komórkowych. Przygotowali dla nich specjalne oferty dotyczące najczęściej tańszych połączeń na Ukrainę. Do tego grona należeli także przewoźnicy, proponując korzystne połączenia między polskimi i ukraińskimi miastami. Dotyczyło to połączeń autobusowych, kolejowych i lotniczych (Szkwarek, 2017). Przykłady te pokazują, że Ukraińcy nie tylko wypełniali lukę w zatrudnieniu, ale także napędzali rozwój gospodarczy między innymi poprzez wzrost zysków firm świadczących dla nich usługi. Zatem ich obecność uaktywniła pewne sektory usług w Polsce. 
Chcąc przeanalizować aktywność Ukraińców na polskim rynku pracy napotyka się na wiele trudności. Jedna $\mathrm{z}$ nich związana jest $\mathrm{z}$ brakiem zintegrowanego systemu danych o imigrantach zatrudnionych na polskim rynku pracy. Informacje na ich temat można czerpać z danych udostępnianych przez Ministerstwo Rodziny, Pracy i Polityki Społecznej oraz Zakład Ubezpieczeń Społecznych. Ponadto statystyki dotyczące zatrudnienia imigrantów publikowane przez Główny Urząd Statystyczny, w ocenie NBP, nie uwzględniają wszystkich zatrudnionych z uwagi na to, iż z powodów definicyjnych imigranci zatrudnieni na krótkie okresy (poniżej 12 miesięcy) nie są ujmowani w Badaniu Aktywności Ekonomicznej Ludności (BAEL). Są oni również niewidoczni w sprawozdaniach przedsiębiorstw, które wykazują osoby zatrudnione na etacie, a nie umowach cywilnoprawnych lub niezgodnie z prawem (Roszkowska, Saczuk, Skibińska, Strzelecki, Wyszyński, 2017, s. 4). Według szacunków NBP w 2016 roku liczba imigrantów obecna na polskim rynku pracy mogła wynieść w granicach 600 000-800 000. Stanowili oni 4-5\% ogółu osób pracujących według BAEL (ibidem, s. 5).

Rosnąca liczba ukraińskich pracowników zatrudnionych legalnie wpłynęła pozytywnie na stan polskiego systemu ubezpieczeń. Płacenie składek w Polsce opłacało się Ukraińcom. Miało to związek z podpisaniem dwustronnej umowy o zabezpieczeniu społecznym w 2012 roku (weszła w życie 1 stycznia 2014 roku - Umowa, 2013). Została ona oparta między innymi na zasadach zachowania praw nabytych i zsumowania okresu ubezpieczenia. Na podstawie pierwszej z nich świadczenia nabyte na mocy prawa jednej ze stron umowy nie mogą być zmniejszane, zawieszane, uchylane, wstrzymane z powodu zamieszkiwania osoby uprawnionej do świadczeń na terenie drugiej strony umowy. Fakt ten nie może mieć negatywnego wpływu na prawo i wysokość wypłacanych świadczeń (art. 5 Umowy, 2013). Na mocy drugiej z wyżej wymienionych zasad nastąpi zsumowanie okresów ubezpieczenia nabytych pod działaniem polskiego i ukraińskiego prawa, które w jego myśl są niezbędne do nabycia lub zachowania prawa do świadczeń z zabezpieczenia społecznego oraz obliczenia wymiaru świadczeń (art. 9-10, 12, Umowy, 2013).

Według danych Zakładu Ubezpieczeń Społecznych, od 2012 do 2017 roku, liczba cudzoziemców odprowadzająca składki ubezpieczeniowe stale wzrastała. W 2016 roku przekroczyła ona 1000000 osób. Wśród nich najliczniejszą narodowością byli Ukraińcy. Ich udział w ogólnej liczbie imigrantów wahał się od 32\% do $71 \%$ w 2017 roku. 
Wykres 1. Liczba Ukraińców odprowadzająca składki do ZUS na tle ogólnej liczby imigrantów płacących składki w latach 2012-2017

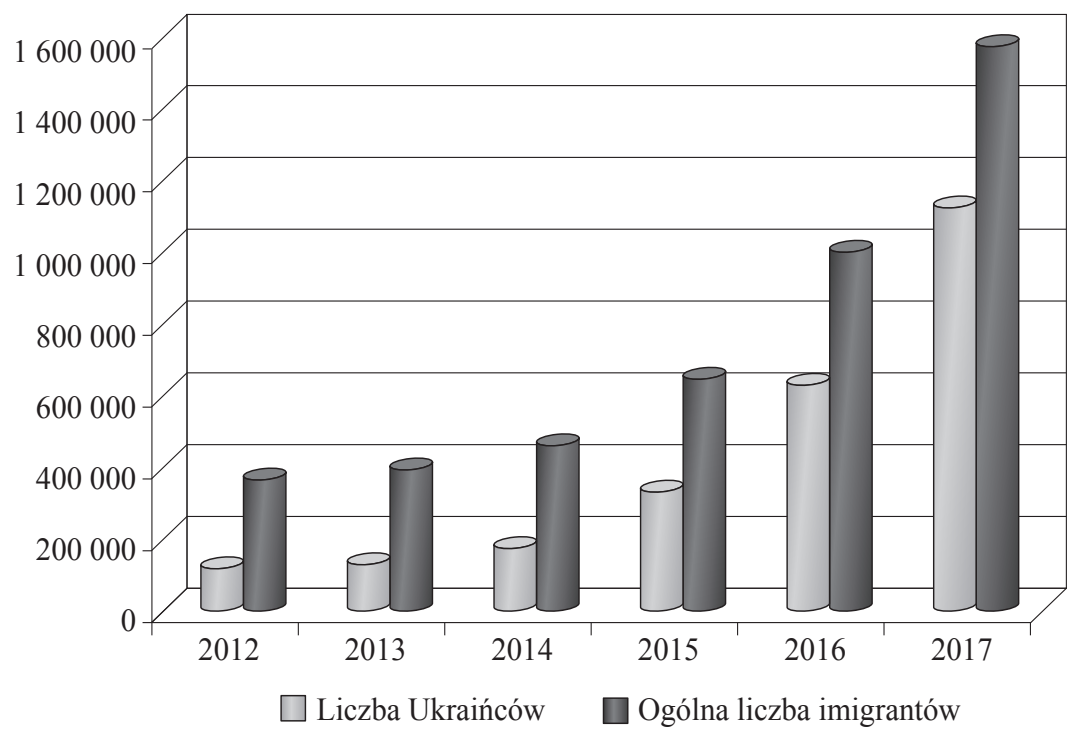

Źródło: Opracowanie własne na podstawie: Ubezpieczenia emerytalne $i$ rentowe, Dane statystyczne ZUS za lata 2010-2017, http://psz.zus.pl/kategorie/ubezpieczeni/ubezpieczenia-emerytalne-i-rentowe, 15.01.2018.

Innym źródłem wiedzy na temat liczby ukraińskich pracowników na polskim rynku pracy były także dane dotyczące wydanych wiz w celu podjęcia pracy. Według informacji statystycznych konsulatu polskiego we Lwowie wydano w 2016 roku 515711 wiz, z czego 256348 ze względu na pracę (50\%), a rok później 444171 wiz, w tym 292856 z powodu chęci podjęcia w Polsce pracy (66\%) (Liczba, 2017). Dane dotyczące wydanych wiz w celu podjęcia pracy przez inne polskie konsulaty były niedostępne.

Niezbędnej wiedzy na temat dynamiki i struktury podaży pracowników z Ukrainy dostarczają dane statystyczne dotyczące liczby wydanych zezwoleń indywidualnych na pracę i oświadczeń wystawionych przez polskich pracodawców. Analiza tych informacji potwierdza tezę o rosnącej liczbie Ukraińców na rodzimym rynku pracy.

Liczba wydawanych zezwoleń indywidualnych, w latach 2014-2017, wzrastała w szybkim tempie. Widoczne to było szczególnie między 2015 a 2016 oraz 2016 i 2017 rokiem. Wówczas ich stan podniósł się o 61608 
oraz 106 507. Miało to związek z rosnącą liczbą obywateli Ukrainy zainteresowanych podjęciem pracy w Polsce. Zezwolenia indywidualne dla nich w stosunku do ogółu wzrosły, w latach 2014-2016, z 60 do 83\%. W 2016 roku liczba wydanych zezwoleń przekroczyła 100 000, a rok później $200000^{2}$.

Wykres 2. Ogólna liczba wydanych zezwoleń indywidualnych na pracę dla cudzoziemców w latach 2014-2017 (w liczbach bezwzględnych) na tle zezwoleń dla Ukraińców

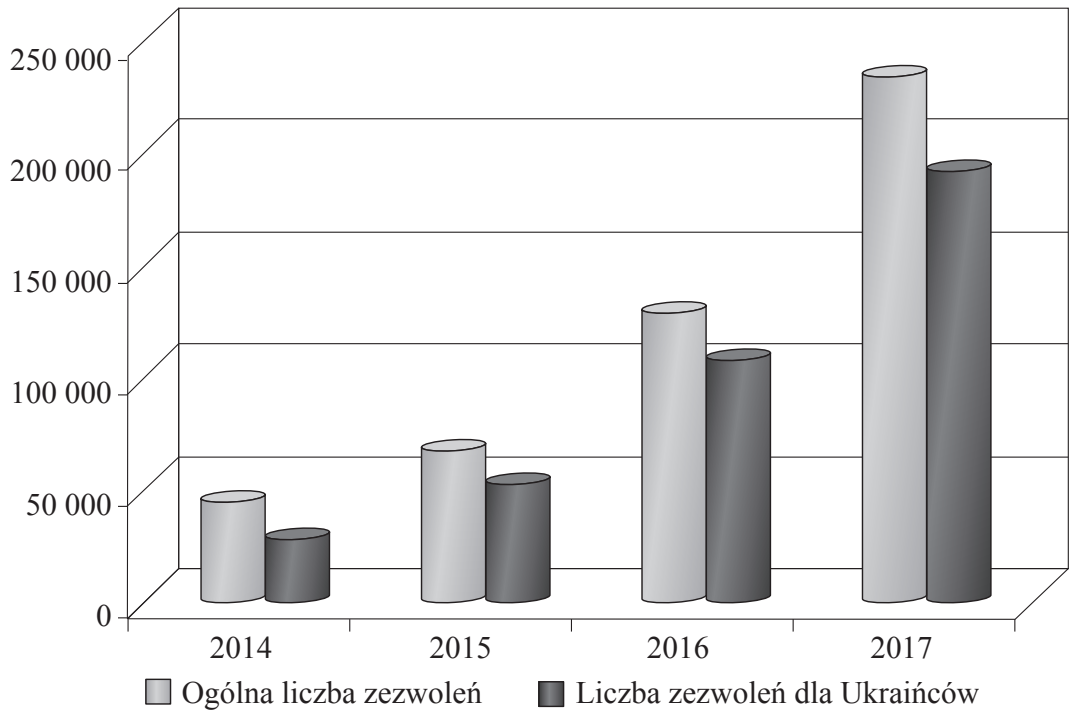

Źródło: Opracowanie własne na podstawie danych statystycznych: Cudzoziemcy pracujqcy w Polsce, Ministerstwo Rodziny, Pracy i Polityki Społecznej, https://www.mpips.gov. pl/analizy-i-raporty/cudzoziemcy-pracujacy-w-polsce-statystyki/, 15.01.2018.

Największa liczba zezwoleń dla Ukraińców przypadła na województwo mazowieckie. W latach 2014-2017 przyznano ich 129609 (z czego 42\% w 2017 roku). Udział tego województwa w ogólnej liczbie przyznanych zezwoleń Ukraińcom, w analizowanym okresie, obniżał się. W 2017 roku wyniósł 28,5\% podczas, gdy wcześniej był równy: 35\%

${ }^{2}$ Wszystkie dane zostały opracowane przez autora na podstawie danych statystycznych ujętych w: Cudzoziemcy pracujacy w Polsce, Ministerstwo Rodziny, Pracy i Polityki Społecznej, https://www.mpips.gov.pl/analizy-i-raporty/cudzoziemcy-pracujacy-w-polsce-statystyki/, 15.01.2018. 
w 2016 roku, 47\% w 2015 roku i 53\% w 2014 roku. Gdy zainteresowanie pracą na terenie województwa mazowieckiego spadało, to wzrastała chęć podjęcia zatrudnienia w innych regionach. Do nich zaliczały się województwa: małopolskie (wzrost z 1746 w 2014 roku do 18230 w 2017 roku), dolnośląskie (wzrost z 970 w 2014 roku do 9602 w 2016 roku), wielkopolskie (wzrost z 1810 do 19045 w latach 2014-2017). W ostatnim badanym roku pracownicy ukraińscy chętniej wybierali także pracę na terenie województw śląskiego i łódzkiego. Nie zmieniał się natomiast popyt na pracę Ukraińców w województwach: podlaskim, podkarpackim i warmińsko-mazurskim. Na tych terenach wydano najmniejszą liczbę zezwoleń indywidualnych dla Ukraińców.

Biorąc pod uwagę typ zezwolenia, w badanym okresie, dominował typ A. Dotyczy on cudzoziemca wykonującego pracę na terenie RP na podstawie umowy z podmiotem, którego siedziba, zakład, oddział znajduje się w Polsce. Ten typ zezwoleń stanowił od 2014 roku ponad 90\%. Zezwolenie typu A cieszyło się także powodzeniem wśród Ukraińców. Od 2014 roku stanowiło ono ponad 95\% ogólnie zarejestrowanych zezwoleń. Zezwolenia na pracę były najczęściej wydawane na okres od 3 miesięcy do roku (około 70\%). Trafiały one przede wszystkim do pracowników wykwalifikowanych, później do pracowników zatrudnianych przy pracach prostych. Najmniej Ukraińców z zezwoleniami zasilało kadrę kierownicza, doradców i ekspertów. Najwięcej zezwoleń dla Ukraińców wydano w branżach: budownictwo, transport i gospodarka magazynowa.

Analiza zatrudniania Ukraińców na podstawie oświadczeń o powierzeniu wykonywania pracy cudzoziemcowi również wskazuje na wzrost udziału Ukraińców na polskim rynku pracy. Poza nimi, ta forma zatrudniania dotyczyła także Białorusinów, Rosjan, Mołdawian, Gruzinów i Ormian. W okresie od 2014 do 2017 roku ogólna liczba zarejestrowanych oświadczeń wzrosła z 387398 w 2014 roku do 1824464 trzy lata później. Wśród imigrantów podejmujących w Polsce pracę na podstawie oświadczenia najwięcej było Ukraińców. W badanym okresie stanowili oni od $94 \%$ do $97,5 \%$. Prawie połowa wydanych oświadczeń dla Ukraińców w 2016 i 2017 roku przypadała na trzy województwa. Wśród nich były: mazowieckie, dolnośląskie i wielkopolskie. Należy zauważyć, iż pierwsze z nich straciło pozycję lidera. Podczas, gdy w 2014 roku powiatowe urzędy pracy rozlokowane na terenie województwa mazowieckiego zarejestrowały 52\% ogólnej liczby oświadczeń w skali kraju, to rok później wskaźnik ten obniżył się do 40\%, aż w 2017 roku spadł do $22,7 \%$. Najmniejszym zainteresowaniem cieszyły się województwa war- 
mińsko-mazurskie, podlaskie i podkarpackie (podobnie, jak w przypadku wydanych zezwoleń na pracę).

Wśród Ukraińców, których oświadczenia zostały zarejestrowane dominowali mężczyźni. Udział kobiet od 2014 roku obniżył się z 38,5\% do $34,5 \%$ (przy czym w latach 2008-2013 wahał się między 38\% a 49\%). Wnioskodawcy oświadczeń byli osobami młodymi. W latach 2014-2017 najliczniejsze grono było w wieku między 26 a 40 lat (43-45\%), między 41 a 60 lat (28-30\%) i poniżej 26 lat (26\%). Wzrost rejestrowanych oświadczeń miał miejsce w okresach wiosennych i letnich, co potwierdza sezonowość pracy Ukraińców w Polsce.

\section{Wykres 3. Liczba zarejestrowanych oświadczeń dla Ukraińców przez powiatowe urzędy pracy, w latach 2014-2017, w podziale na miesiące}

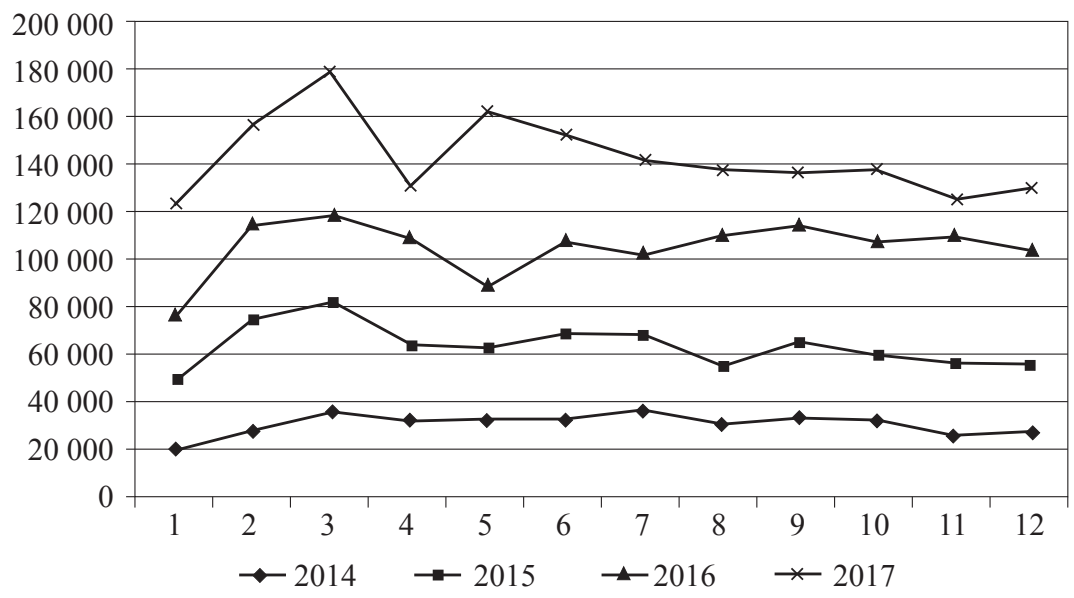

Źródło: Opracowanie własne na podstawie danych Ministerstwa Rodziny, Pracy i Polityki Społecznej za lata 2014-2017, http://psz.praca.gov.pl/rynek-pracy/statystyki-i-analizy/zatrudnianie-cudzoziemcow-w-polsce, 15.01.2018.

Sezonowość ta widoczna była także w podziale zarejestrowanych oświadczeń na sekcje PKD. W latach 2014-2017 dominowało rolnictwo (leśnictwo, łowiectwo i rybactwo). Mimo, iż w sekcji tej najwięcej było zatrudnionych Ukraińców, to jednak widoczny był spadek atrakcyjności tego działu. Podczas, gdy w 2014 roku liczba zarejestrowanych oświadczeń dla tej sekcji wyniosła $47 \%$ w stosunku do wszystkich oświadczeń, to już trzy lata później spadła do $17,7 \%$. Obniżył się także udział w sekcjach budownictwa (z 14\% do 12,5\%) oraz gospodarstwa domowe 
(z 3,4\% do 0,8\%), a podniósł się w sekcjach: przetwórstwo przemysłowe, transport i gospodarka magazynowa. Najpopularniejszą grupą zawodową, dla której rejestrowano oświadczenia był robotnik wykonujący proste prace. Ich udział w ogólnej liczbie zarejestrowanych oświadczeń, w latach 2014-2017, wahał się między 55 a 66\% i obniżał się. Wzrost odnotowano między innymi w przypadku grup - robotnicy przemysłowi i rzemieślnicy (z 12\% do 18\%) oraz operatorzy i monterzy maszyn i urządzeń (z 2,7\% do 11\%).

Pracodawcy rejestrując oświadczenia deklarowali najczęściej zamiar powierzenia pracy na podstawie umowy o dzieło. Było to jednak charakterystyczne dla lat 2014-2015, gdy udział tego rodzaju umów w ogólnej liczbie wyniósł 52\% i 44,7\%. W 2016 spadł on do poziomu 32\%, a rok później - 19,8\%. W 2016 i 2017 roku dominowały umowy zlecenia (w kolejności 48\% i 55\%). W badanym okresie najrzadziej rejestrowano oświadczenia z zamiarem powierzenia pracy na podstawie umowy o pracę, choć ich udział zwiększał się (w kolejności 14\%, 15\%, 19\%, 24,5\%).

Część Ukraińców pracująca w Polsce była także zatrudniona nielegalnie. Ich udział z roku na rok zwiększał się. Z danych Państwowej Inspekcji Pracy wynika, iż w 2016 roku nastapił wzrost ujawnionych przypadków nielegalnego powierzenia pracy o $18 \% \mathrm{w}$ porównaniu do roku poprzedniego. Największą grupą narodowościową byli Ukraińcy. W 2016 roku stanowili oni 96\% ujawnionych przypadków (4 982 osoby, Sprawozdanie, 2017b, s. 97), a we wcześniejszych okresach 88\% w 2015 roku i 78\% w 2014 roku (Sprawozdanie, 2016, s. 139). Nielegalność miała związek przede wszystkim z brakiem odpowiedniego zezwolenia na pracę. Pracownicy godzili się na taką formę, gdyż dzięki temu mogli zarobić więcej niż pracując legalnie. Zapominali jednak o ryzyku związanym z wypadkiem czy chorobą.

Mimo, iż większość pobytów związanych z pracą miała charakter krótkoterminowy, to jednak można zauważyć, iż coraz częściej obywatele Ukrainy inwestowali w nieruchomości w Polsce. Miało to związek nie tylko z emigracją zarobkową, ale także naukową. Analizując dane dotyczące powierzchni lokali (mieszkalnych i użytkowych) nabytych przez osoby fizyczne będące cudzoziemcami można stwierdzić, iż Ukraińcy w 2016 roku byli w tym względzie liderem. Nabyli łącznie ponad $69000 \mathrm{~m}^{2}$ powierzchni i tym samym pokonali Niemców, którzy do tego roku nabywali najwięcej powierzchni lokali ${ }^{3}$ (Sprawozdanie, 2017a, s. 77-79). Obszary

${ }^{3}$ Wnioski na podstawie analizy sprawozdań Ministra Spraw Wewnętrznych i Administracji z realizacji ustawy z dnia 24 marca 1920 r. o nabywaniu nieruchomości przez cudzoziemców za lata 2014-2016. 
województw, na terenie których kupowano najwięcej lokali pokrywały się z tymi, na których wydano najwięcej zezwoleń na pracę i oświadczeń o zamiarze powierzenia pracy. Najchętniej nabywano lokale mieszkalne i użytkowe w dużych miastach, jak na przykład: Warszawie, Krakowie, Wrocławiu, Gdańsku czy Poznaniu (ibidem, s. 50). Wśród kupujących byli rodzice studiujących w Polsce dzieci ukraińskich, rodziny z dziećmi, ukraińscy inwestorzy kupujący mieszkania pod wynajem oraz pracownicy korporacji (Ukraińcy, 2017).

Badając aktywność ukraińskich pracowników na polskim rynku pracy należy stwierdzić, iż na razie nie widać ich wpływu na wynagrodzenia pracowników lokalnych oraz poziom bezrobocia. W opinii $50 \%$ zbadanych powiatowych urzędów pracy obecność cudzoziemców na lokalnym rynku pracy miała charakter neutralny. $69 \%$ z nich przewidywała, że w 2017 roku wzrośnie na ich pracę zapotrzebowanie. Wśród najczęściej wymienianych powodów zatrudniania cudzoziemców była propozycja niższego wynagrodzenia (72\%) oraz brak Polaków chętnych do podjęcia pracy (18\%) (Informacja, 2016, s. 9).

Podsumowując powyższe rozważania należy stwierdzić, iż w Polsce przy braku polityki migracyjnej nie ma systemu zarządzania migracjami zarobkowymi. Mimo, iż w art. 90 ust. 10 ustawy o promocji zatrudnienia i instytucjach rynku pracy mowa jest o „celach polityki migracyjnej”, którymi winien kierować się minister właściwy ds. pracy (Ustawa, 2017). Nie mamy wypracowanych rozwiązań mogących zatrzymać zagranicznych pracowników na dłużej niż kilka miesięcy w państwie. Nie dysponujemy także pogłębionymi analizami dotyczącymi wpływu imigracji zarobkowej na polski rynek pracy. Ponadto przedstawiciele władz nie zaaranżowali do tej pory dyskusji na ten temat mimo, iż jest to ważne zagadnienie zważywszy na fakt, że liczba pracujących w Polsce cudzoziemców rośnie. Dotyczy to zarówno zatrudnienia zgodnie z prawem, jak i w szarej strefie. W ostatnim okresie zaproponowane zmiany prawne w zakresie zatrudniania cudzoziemców są działaniami ad hoc. Co prawda idą one w kierunku liberalizacji dostępu do rynku pracy, ale jednak nie wynikają one z przemyślanej polityki migracyjnej. Zauważyć można także wzrost kontroli nad cudzoziemcami chcącymi zatrudnić się w Polsce, jak i pracującymi. Ma to związek z zachowaniem bezpieczeństwa i porządku publicznego, jak napisano w ustawie o promocji rynku pracy. Przejawia się to między innymi kontrolą liczby wydawanych zezwoleń na pracę, na pracę sezonową i oświadczeń (art. 90b ust. 1-3, Ustawa, 2017). 
Analizując aktywność Ukraińców na rynku pracy można stwierdzić, iż dopasowali się oni niemal idealnie do popytu. Wybierali na swoją aktywność zawodową obszary województw, które dysponowały największą liczbą wolnych etatów, a unikali tych z najskromniejszą oferta, czyli podlaskiego, świętokrzyskiego i warmińsko-mazurskiego. Ponadto wypełniali luki w zawodach, które oferowały najwięcej wolnych miejsc. Oznacza to, że ich obecność na polskim rynku pracy rozwiązywała problemy kadrowe polskich pracodawców. Równoważyła także skutki spadku liczby osób aktywnych zawodowo, przyczyniając się do wzrostu zatrudnienia i tym samym wzrostu gospodarczego. Warto także podkreślić, iż część zarobków Ukraińcy wydawali na bieżące potrzeby, zwiększając produkt krajowy brutto. Odprowadzali także składki na ubezpieczenie społeczne, wpływając na równoważenie finansów publicznych. Należy ponadto zauważyć, iż Ukraińcy nie stanowili dla Polaków konkurencji na rodzimym rynku pracy.

Ich aktywność została dostrzeżona i w rankingu 50 najbardziej wpływowych ludzi polskiej gospodarki w 2017 roku sporządzonej przez „Gazetę Prawną” Ukraińcy znaleźli się na drugim miejscu. Zostali uznani za „zbiorowy bohater polskiej gospodarki” (Oto, 2018).

\section{Bibliografia}

Adamczyk A. (2012), Spoteczno-polityczne implikacje imigracji do Polski w latach 1989-2007, Poznań.

Barometr imigracji zarobkowej, II pótrocze 2017. Ukraiński pracownik w Polsce (2017), Raport Personnel Service, http://personnelservice.pl/pl/biuro-prasowe/raporty, 20.01.2018.

Все більше українців хочуть переїхати жити закордон (2016), https://tns-ua.com/ news/vse-bilshe-ukrayintsiv-hochut-pereyihati-zhiti-zakordon, 20.01.2018.

Бойко М. (2017), Україна без украӥнців: до чого призведе заробітчанство, 4.10.2017 r., http://vgolos.com.ua/articles/ukraina_bez_ukraintsiv_do_chogo_pryzvede_zarobitchanstvo_284902.html, 20.01.2018.

Chmielewska I., Dobroczek G., Puzynkiewicz J. (2016), Obywatele Ukrainy pracujacy $w$ Polsce - raport z badania, Badanie zrealizowano w 2015 r., Departament Statystyki NBP, Warszawa.

Скільки украӥнців хочуть виїхати за кордон і де хочуть прачювати: результати дослідження (2017), http://www.tutkatamka.com.ua/cikavinki/opituvannya/ skilki-ukra\%D1\%97nciv-xochut-vi\%D1\%97xati-za-kordon-i-de-xochut-pracyuvati-rezultati-doslidzhennya/, 22.01.2018. 
Danielewicz M. (2018), Powiatowy Urzad Pracy w Poznaniu: Pracodawcy czekaja długie godziny w kolejkach, „Głos Wielkopolski” 14.02 .2018 r., http://www. gloswielkopolski.pl/strefa-biznesu/wiadomosci/a/powiatowy-urzad-pracyw-poznaniu-pracodawcy-czekaja-dlugie-godziny-w-kolejkach,12932942/, 16.02.2018.

Dyrektywa Parlamentu Europejskiego i Rady 2014/36/UE z dnia 26 lutego 2014 r. w sprawie warunków wjazdu i pobytu obywateli państw trzecich w celu zatrudnienia w charakterze pracownika sezonowego, Dz. U. UE L 2014.94.375.

Інфляиійний звіт (2018), Національний банк України, січня 2018 року, https:// bank.gov.ua/doccatalog/document?id=63442010, 10.02.2018.

Informacja nt. zatrudnienia cudzoziemców w Polsce (grudzień 2016), MRiPS Department Rynku Pracy, https://www.mpips.gov.pl/gfx/mpips/userfiles/_public/1_NOWA\%20STRONA/Analizy\%20i\%20raporty/cudzoziemncy\%20 pracujacy $\% 20 \mathrm{w} \% 20$ polsce/zatrudnianie $\% 20$ cudzoziemcow\%202016.pdf, 16.01.2018.

Keryk M. (2017), Problemy imigrantów z Ukrainy, w: Imigranci wsparciem dla rynku pracy i rozwoju przedsiębiorstw, pod red. T. Kupczyk, Wrocław.

Кожен другий украӥнець шукає роботу за кордоном. Статистика (2017), http:// prompolit.info/2017/10/03/kozhen-drugij-ukrayinets-shukaye-robotu-zakordonom/, 16.01.2018.

Liczba wydanych wiz i odmów w 2016 i 2017 r. (2017), Konsulat Generalny RP we Lwowie, http://www.lwow.msz.gov.pl/pl/konsulat/statystyki/, 16.01.2018.

Monitoring rynku pracy. Popyt na prace w III kwartale 2017 roku (2017), Opracowanie sygnalne, Główny Urząd Statystyczny, 8.12.2017 r. Warszawa.

Oto ranking 50 najbardziej wptywowych ludzi polskiej gospodarki (2018), „Gazeta Prawna" 9.02.2018 r., http://biznes.gazetaprawna.pl/artykuly/1103285,ranking50-najbardziej-wplywowych-ludzi-polskiej-gospodarki.html, 16.02.2018.

Перспективні украӥниі дедалі частіше виїжджають закордон: статистика (2017), http://svitua.com.ua/news/201701/2236-perspektyvni-ukrayinci-dedali-chastishe-vyyizhdzhayut, 16.01.2018.

Poland - Gross domestic product per capita in current proces, World Data Atlas, https://knoema.com/atlas/Poland/GDP-per-capita, 16.01.2018.

Poland - Unemployment rate, World Data Atlas, https://knoema.com/atlas/Poland/ Unemployment-rate, 16.01.2018.

Popyt na prace w 2016 r. (2017), GUS Departament Badań Demograficznych i Rynku Pracy, Warszawa.

Powstat zwiazek zawodowy pracowników ukraińskich w Polsce (2017), http://www. opzz.org.pl/aktualnosci/swiat/powstal-zwiazek-zawodowy-pracownikowukrainskich-w-polsce, 11.01.2018.

Roszkowska S., Saczuk K., Skibińska M., Strzelecki P., Wyszyński R. (2017), Kwartalny raport o rynku pracy w I kw. 2017 r., Wydział Gospodarstw Domowych i Rynku Pracy Departament Analiz Ekonomicznych NBP, Warszawa, 
https://www.nbp.pl/publikacje/rynek_pracy/rynek_pracy_2017_1 kw.pdf, 11.01.2018.

Rozgryźć niedobór talentów (2016), ManpowerGroup, Warszawa, http://www.manpowergroup.pl/wp-content/uploads/2016/09/2016_Raport_Niedob\%C3\%B3r_ talent\%C3\%B3w-info.-prasowa-ManpowerGroup.pdf, 11.01.2018.

Rozporządzenie Ministra Rodziny Pracy i Polityki Społecznej z dnia 7 grudnia 2017 r. w sprawie wydawania zezwolenia na prace cudzoziemca oraz wpisu oświadczenia powierzeniu wykonywania pracy cudzoziemcowi do ewidencji (2017a), Dz. U. 2017, poz. 2345.

Rozporządzenie Ministra Rodziny Pracy i Polityki Społecznej z dnia 8 grudnia 2017 r. $w$ sprawie wysokości wpłat dokonywanych $w$ zwiqzku ze złożeniem wniosku o wydanie zezwolenia na prace lub zezwolenia na prace sezonowa oraz złożeniem oświadczenia o powierzeniu wykonywania pracy cudzoziemcowi (2017b), Dz. U. 2017, poz. 2350.

Rozporządzenie Ministra Rodziny Pracy i Polityki Społecznej z dnia 8 grudnia 2017 r. w sprawie państw, do których obywateli stosuje się niektóre przepisy dotyczqce zezwolenia na prace sezonowa oraz przepisy dotyczqce oświadczenia o powierzeniu wykonywania pracy cudzoziemcowi (2017c), Dz. U. 2017, poz. 2349.

Rozporządzenie Ministra Rodziny Pracy i Polityki Społecznej z dnia 8 grudnia 2017 r. w sprawie państw podklas działalności wedlug Polskiej Klasyfikacji Działalności (PKD), w których wydawane sq zezwolenia na prace sezonowa cudzoziemca, Dz. U. 2017, poz. 2348.

rt, adom (2017), Ukraińcy mogq wjeżdża do UE bez wiz. Jak zareaguje polski rynek pracy?, TVP info, 11.06.2017 r., https://www.tvp.info/32768672/ukraincy-moga-wjezdzac-do-ue-bez-wiz-jak-zareaguje-polski-rynek-pracy, 11.01.2018.

Sprawozdanie Ministra Spraw Wewnętrznych i Administracji z realizacji w $2016 \mathrm{r}$. ustawy z dnia 24 marca 1920 r. o nabywaniu nieruchomości przez cudzoziemców (2017a), Warszawa, https://www.mswia.gov.pl/pl/bezpieczenstwo/ koncesje-i-zezwolenia, 11.01.2018.

Rozporządzenie Parlamentu Europejskiego i Rady (UE) 2017/850 z dnia 17 maja 2017 r. zmieniajace rozporzqdzenie Rady (WE) $n r$ 539/2001 wymieniajace państwa trzecie, których obywatele musza posiadać wizy podczas przekraczania granic zewnętrznych, oraz te, których obywatele sq zwolnieni z tego wymogu (Ukraina), Dz. U. UE L 2017.133.1.

Rozporządzenie Rady (WE) nr 539/2001 z dnia 15 marca 2001 r. wymieniajace państwa trzecie, których obywatele muszq posiadać wizy podczas przekraczania granic zewnętrznych, oraz te, których obywatele sq zwolnieni z tego wymogu, Dz. U. UE L 2001.81.1.

Sprawozdanie z działalności Państwowej Inspekcji Pracy w 2016 roku (2017), Warszawa, https://www.pip.gov.pl/pl/f/v/176401/Sprawozdanie\%202016.pdf\#pa$\mathrm{ge}=91,13.01 .2018$. 
Sprawozdanie z działalności Państwowej Inspekcji Pracy w 2015 roku (2016), Warszawa, https://www.pip.gov.pl/pl/f/v/156451/Sprawozdanie\%202015.pdf\#pa$\mathrm{ge}=131,13.01 .2018$.

Szkarek W. (2017), Już nie pracownik, a klient. Polski biznes dostrzegt Ukraińców, Bankier.pl 28.03.2017, https://www.bankier.pl/wiadomosc/Juz-niepracownik-a-klient-Polski-biznes-dostrzegl-Ukraincow-7507340.html, 15.01.2018.

The average salary in Ukraine is USD 188 per month (2016), http://blogs.elenasmodels.com/en/average-salary-ukraine-2016/, 15.01.2018.

Ubezpieczenia emerytalne i rentowe cudzoziemców, http://psz.zus.pl/kategorie/ubezpieczeni/ubezpieczenia-emerytalne-i-rentowe, 15.01.2018.

Ukraine - Gross domestic product per capita in current proces, World Data Atlas, https://knoema.com/atlas/Ukraine/GDP-per-capita, 16.01.2018.

Ukraine - Unemployment rate, World Data Atlas, https://knoema.com/atlas/Ukraine/ Unemployment-rate, 16.01.2018.

Ukraińcy kupuja w Polsce mieszkania za gotówkę. Dwa miasta sq wyjatkowo popularne (2017), https://businessinsider.com.pl/finanse/mieszkania-w-polscekupuja-ukraincy/74rzk2p, 16.01.2018.

Umowa między Rzecząpospolitą Polską a Ukrainą o zabezpieczeniu społecznym, sporządzono w Kijowie dnia 18 maja 2012 roku, Dz. U. 2013, poz. 1373, 1375.

Ustawa z dnia 26 maja 2017 r. o promocji zatrudnienia i instytucjach rynku pracy (2017), Dz. U. 2017, poz. 1065.

Wrotniak M. (2017a), Ukraińcy dominuja wśród zagranicznych klientów banków, Bankier.pl 22.11.2017 r., https://www.bankier.pl/wiadomosc/Ukraincy-dominuja-wsrod-zagranicznych-klientow-bankow-7557501.html, 16.01.2018.

Wrotniak M. (2017b), Oferta banków dla obywateli Ukrainy, Bankier.pl 22.12.2017 r., https://www.bankier.pl/wiadomosc/Oferta-bankow-dla-obywateli-Ukrainy-7562395.html, 26.01.2018.

Wynagrodzenia w Polsce według danych GUS, Przeciętne miesięczne wynagrodzenia $w$ ujęciu miesięcznym, kwartalnym i rocznym, https://wynagrodzenia.pl/gus, 16.01.2018.

Zatory przy wydawaniu pozwoleń. Urzędy pracy nieprzygotowane na zmiany $w$ zatrudnianiu cudzoziemców (2018), http://personnelservice.pl/pl/aktualnosci/ zatory-przy-wydawaniu-pozwolen-urzedy-pracy-nieprzygotowane-na-zmiany-w-zatrudnianiu-cudzoziemcow, 16.01.2018.

Zniesienie obowiazku wizowego wobec obywateli Ukrainy - konsekwencje migracyjne dla Unii Europejskiej, Ekspertyza Ośrodka Studiów Wschodnich, 16 październik 2017 r.

Żebrowski P., Dyjak G. (2017), Eksperci: grupy przestępcze próbuja rejestrować fikcyjne oświadczenia dla cudzoziemców, „Gazeta Prawna”, 16.12.2017 r., http:// www.gazetaprawna.pl/artykuly/1092495,eksperci-grupy-przestepcze-probuja-rejestrowac-fikcyjne-oswiadczenia-dla-cudzoziemcow.html, 16.01.2018. 
Economic immigration to Poland. The case of Ukrainians (2014-2017)

\section{Summary}

The aim of the paper is to analyze the economic immigration of Ukrainians to Poland from 2014-2017. It presents the data obtained by Ukrainian and Polish institutions researching the migration of Ukrainian employees. Statistics related to their activity in the Polish labor market are analyzed. The article shows the influence of Ukrainian employees on the economic development in Poland. The main thesis of the article is that Ukrainian employees have had a positive impact on the development of Polish economy.

Key words: labor immigration, Ukrainians, the labor market, foreigners 
